\title{
Demonstration Method, its influence on Knowledge and Practice of Baby Massage among Traditional Birth Attendants
}

\author{
Mayestika Eka Nur Fitriana ${ }^{1)}$,Siti Rofi'ah²), Munayarokh²) \\ mayestikae@yahoo.co.id \\ Health Polytechnic of Semarang \\ Midwifery Study Program of Magelang
}

\begin{abstract}
Background: The community still uses the power of a Traditional Birth Attendant (TBA) as infant massager because the TBA is considered to provide help with emotional security through prayers and is considered to be part of the social and cultural environment. Herbalists in villages typically show non-conforming massage methods and are even at risk for trauma injury to infants, the most dangerous of which TBA perform inappropriate massage on the abdomen and head.
\end{abstract}

Purpose: The purpose of this research is to know the effect of health education by way of demonstration method for TBA in work area of Selopampang and Tembarak Public Health Center, Temanggung Regency

Methods: This study used pre experimental studies with one group of pretest - posttest design and qualitative and quantitative types. Sampling technique is by total sampling. All samples were given a questionnaire to measure the level of education and practice for infant massage.

Result: The results showed that demonstration is the effective method for improving knowledge and practice with the result of T-Test statistical analysis p-value 0.000 .

Conclusion: It is expected that health personnel need to update the concepts needed to train children and children can apply the skills in accordance with the theory, so as to produce maximum results to create the next generation of quality.

Keyword :Demonstration Method, Knowledge, Practice, Baby massage, Traditional Birth Attendant.

1) Student of Midwifery Study Program of Magelang, Poltekkes Kemenkes Semarang

2) Lecturer of Midwifery Study Program of Magelang, Poltekkes Kemenkes Semarang

Background. Indonesia as one of the countries that have agreed to the implementation of sustainable development goals (SDGs) and is committed to the successful implementation of SDGs through various activities and has taken strategic steps. Indonesia requires its youth generation who have good quality to be able to resolve the problems that hit this country and determine the future of the nation. As explained by one goal of SDGs, the Good Health and Welfare, ensure a healthy life and encourage well-being for all people in all ages. Besides, most of the younger generation of today forget their own identity, by the decrease in attitude and moral leading to the need for the early stimulus in order to get psychomotor and mental development so they can make indonesia better and has a hight quality of its generation through baby massage.

Massage therapy is the oldest known human touch and the most popular as well as art of healthcare and medicine which has been practiced since centuries ago. According to research conducted by (Setyaningsih, Wati, \& Utami, 2015) there is a relation between the baby massage and 
the child's motor development. It is approved by the results of research that the percentage of respondents whose irregular baby massage reach the highest by the number of 24 respondents $(72.73 \%)$, and some who do baby massage on a regular basis totaled 9 respondents $(27.27 \%)$. It shows that all respondents do baby massage although there are regular and irregular. In conclusion, the percentage of normal motor development in the category of a total of $14(42.42 \%)$, delayed a number of $14(42.42 \%)$ and advance as much as $5(15.16 \%)$. In addition, a research conducted by Sudarsih (2015) get results that there is an increased quantity of sleeping in babys aged 3-6 months before and after the baby massage, this is due to baby massage make the blood circulation and oxygen of the child's body will be more fluid, blood on the baby's body will flow to all parts of the body, not the exception on the part of his brain. The results of the study showed that $78.6 \%$ by quantity of sleep before the baby massage unmet be fulfilled, namely $71.4 \%$ and $7.1 \%$ still remains unfulfilled. There are studies that support the baby sleep quality research that is conducted by (Blood Ifalahma, 2016) which have concluded that massage with a longer duration of time is more effective in improving the quality of sleep in baby. According to research conducted by EnnyFitrihadi (2016) came to the conclusion that baby massage effect on the increasing frequency of breastfeeding in babys aged 1-3 months but has no effect on the duration of breastfeeding in babys aged 1-3 months. Additionally, Farida Y (2016) explains that the baby massage effect on the increasing frequency of breastfeeding in babys aged 1-3 months but has no effect on the duration of breastfeeding in babys aged 1-3 months. These researches approved by the increase in the average frequency of breastfeeding twice a day is as much as $36.7 \%, 33.3 \%$ increased from once a day, $13.3 \%$ from $3 \times$ / day increased $6.7 \% 4 \mathrm{x} /$ day and $10 \%$ had no any influence.

Baby massage is not something new in Indonesia. Baby massage is still largely done by traditional masseurs as TBA or shaman. TBA or shaman is a woman who gives aid in pregnancy and childbirth. They generally do not have much knowledge about obstetrics and plays an important role in maternity care. They acquire knowledge from the other maternity helpers who became their teacher also from their experience in everyday practice(Prawirohardjo, 2011). People still go to shaman for baby massage because shaman are considered to bring relief to the emotional security to the mother and family through prayers and felt to have become part of the social and cultural communities(Prawirohardjo, 2011). Traditional shaman in particular shows the way they massage often inconsistent that can cause injury or trauma to the baby, the most dangerous is when the shaman do the massage with head movements and pressing on the baby's abdomen. According to Adelia's research (2014), shaman gaining knowledge from following the way of their senior did instead of the way that has been written on any book reference. Therefore, it is important to organize atraining, coaching and partner with shaman or TBAs (Ambarwati, 2011).

The common health education mediafor shaman or TBA is lecture method. As described in the research conducted by Ambarsari (2017), has the result that an increase in the average before and after counseling, ie from 10.8 into 25.6. The mother ability 
to practices was increased, it showed by the average of 10.8 into 25.6 . In that study was concluded that the mother ability to practice baby massage after given health education was better, it was supported by the lecture methods and demonstrate or practice directly about the proper procedure of baby massage.

To obtain maximum results, researchers used a demonstration method that shows the process of occurrence of an event, until the appearance of behavior in order to understand by the learners whether real or imitation so that the respondents in this research - shaman or TBA will understand the material.

The results of a preliminary survey that has been done in the field of study, the data obtained from the midwife coordinator of Selopampang PHC (Public Health Centre) there are 12 shamans. While in Tembarak Public Health Centre there are 19 shamans. These shamans are no longer active in making aid delivery but is still active in the care of newborn babies in these region. The shamans do the baby massage without training. Even they get knowledge from the senior shaman, they apply the baby massage not only to a healthy baby, but also to the ill or fussy babies. The movements performed by the shaman while massaging have some differences with the theory, that in the guidelines of baby massage are not massaging the parietal and occipital part, just a gentle rubbing motion on face areas and the massage movements on stomach following with the colon anatomy called I LOVE $U$ movement, and these are different from the way the shamans do on massaging the upper head and abdomen. The shamans massaging the abdominal area from top to bottom, starting from left of the baby to the right abdominal of the baby.

From the description above and the various phenomena that occur in the community, the researchers are interested in doing research with the title "Health Education Demonstration Method of Knowledge and Practice of Baby Massage by Shaman".

Objective, The population in this research are shamans in Selopampangand Tembarak Public Health Center in 2018. The data retrieval using secondary data types and data retrieval method using allo anamnesis an interview with the coordinator of shaman in the health center. Measurement scale on this study using ordinal scale on the univariate research and ratio scale on the bivariate research.

In this study, the independent variable is health education demonstration method, while the dependent variable are knowledge and practice of baby massage by shaman. The instruments using questionnaire and checklist sheet. The research was conducted in Selopampang and Tembarak health centers, Temanggung Regency in September 2017- April 2018

Methods. This research is an experimental research with preexperimental design. The design used in this study using preexperimentalresearch study with one group pretest - posttest design.

After the data collected, the next step is processing the data. The data analysis is T-Test Paired test and wilcoxon matched pairs using SPSS software.

\section{Result and Discussion. \\ Result}

1. Shaman's Knowledge Level Description About Baby Massage 
Before Given Health Education of Demonstration Method.

Based on the tabulation results on table 4.1 shows that as many as 12 respondents $(38.7 \%)$ have enough knowledge.

2. Shaman's Practice Description About Baby Massage Before Given Health Education DemonstrationMethod.

Based on the tabulation results on table 4.2 shows there were 18 respondents, or $58.1 \%$ that had a good baby massage skills.

3. Shaman's Knowledge Level Description About Baby Massage After Given Health Education of DemonstrationMethod.

Based on the tabulation results on table 4.3 shows that as many as 19 respondents or $61.3 \%$ had a good knowledge.

4. Shaman's Practice Description About Baby Massage After Given Health Education

DemonstrationMethod.

Based on the tabulation results on table 4.5 shows that there are 17 respondents, or $54.8 \%$ had a good baby massage practice.

5. Analysis of Demonstration Method Effectiveness Against Shaman's Knowledge Level In Practicing Baby Massage.

Based on static analysis table 4.5 obtained the test results Paired $\mathrm{T}$-Test, getting the data mean the $\mathrm{p}$ value 2.7096 (sig 2-tailed) 0000 which constitutes an effective demonstration methods of improving shamans knowledge in performing baby massage.

6. Analysis of Demonstration Method Effectiveness Against Shaman Practices in Baby Massage options.

Based on Table 4.6, the significance results of $\mathrm{T}$ -
TestPairedtest, there is the data mean.

\section{Discussion.}

1. Shaman's Knowledge Level Description About Baby Massage Before Given Health Education of DemonstrationMethod.

In this study, the researchers give baby massage demonstration method of intervention on a shaman that aims to improve the knowledge of shamans because people still rely on traditional healer to care for their baby and treatment. People go to traditional birth attendants because they believe that their pain caused by magical when playing under the tree is not as modern illnesses and assistance were doing pilis so that they can be cured, but it massagers also has a friendly attitude and provide an explanation to the patient by using everyday language so that they have more confidence and be able to understand it.

Based on research by the respondent before giving a demonstration method of baby massage practices found that as many as 19 respondents $(61.3 \%)$ less the value of $<56 \%$ and 12 respondents (38.7\%) have sufficient knowledge of $56-75 \%$ (Henry and Goddess, 2011, h; 18). On the pretest value, no respondents who have either category. This is because respondents have had knowledge of baby massage and descent experience and not of theory and the latest research. Some $97 \%$ of respondents, or as much as 30 shaman answered wrong on the statement number 19, which is massaging baby's finger nails one by one from the baby to the base of the finger in a circular motion. This is because the shaman never update 
the knowledge acquired, so the technique is used only to massage alone. According to Roesli (2016) the baby should not be massaged when the situation is less healthy, but due to lack of knowledge and myths assume that baby massage can heal the pain caused baby massage on less healthy state. In fact, precisely because of the sick babies then parents enlist the services of a shaman to treat it with a massage.

2. Shaman's Practice Description About Baby Massage Before Given Health Education of Demonstration Method.

The results of the data analysis in research of baby massage practice by herbalists through the method of demonstration is a way of presenting the lesson material with demonstrates to students the process of the situation, or particular object being studied, either real or imitation is often accompanied by verbal explanation (Daryanto, 2009), it showed that before getting a health education of demonstration method, respondents have good skills as much as 18 respondents, or $58.1 \%$, and 13 respondents $(41.9 \%)$ have less skill. This study examines the practice of baby massage skills by TBAs in Tembarak and Selopampang Public Health Center commonly performed on babys. This practice skills possessed of experience and culture.

From the analysis before giving health education between good and less skill is not far adrift, it might happen because of personal experience, people who are considered important and emotional factors in an individual according to (Anwar, 2016) The results of the analysis of attachment pretest, showed the data that respondents do not know how to massage the abdomen and head, but this part is very fatal.

On average, respondents do massage without seeing the anatomy of human organs. Respondents also still use ingredients that they believe can assist in the care of the baby. For example, grated ginger, garlic, or herbs are crushed and mixed into the oil without performing allergy tests on the baby's skin first. This herb contains substances that can cause itching, burning, or stinging on baby's skin. It contrast with the guidelines done medically, massage oil used for allergy tests should be done before applying to the surface of the baby's skin to ensure the baby's skin does not have an allergy or irritation caused potions or used oil. The action taken by the respondent is actually less accurate and can harm the baby.

3. Shaman's Knowledge Level Description About Baby Massage After Given Health Education of DemonstrationMethod.

Based on the results of questionnaires posttest of demonstration methods of health education in 31 respondents there were 19 respondents $(61.3 \%)$ categories with a value of $>76 \%$, and 12 respondents $(38.7 \%)$ have sufficient knowledge of the value of 56-75\% (Wawan and goddesses, 2011) Education can affect a person, including a person's behavior will be especially motivating lifestyle to participate in the development stance. In general, the higher a person's education more easily receive information (Wawan and 
goddesses, 2011). The education level of less or low will hinder the development of a person's attitude towards new values introduced. The level of education shamans will affect its ability to absorb a science, so the ability in the implementation of baby massage is still lack.

Awareness of the respondents would ever growing health sciences make respondents were very enthusiastic on baby massage health education. They understand the benefits, things that need to be and should not be done, because massage is a staple of their work, so that information can be received well, evidenced from the increased value of the average questionnaires completed before and after respondents were given a demonstration methods of health education. Shortage of health education delivery that is due to the respondents' education levels vary, age, employment and culture (Wawan and goddesses, 2011), because the average education of respondent only elementary school and some have not. TBAs age who have entered the age of the elderly effect on the absorption of knowledge.

4. Shaman's Knowledge Level Description About Baby Massage After Given Health Education of DemonstrationMethod.

Skill is a continuation of the results of cognitive (understanding something) and affective (actions or behaviors) (Notoatmodjo, 2010), In this study, after a demonstration methods of health education, statistical tests showed no decrease in the results of practical skills by TBAs. Less skill than the data prior to the intervention, there were 13 respondents, to 14 respondents. This is because the value of practical skills gained on average higher in value than the pretest posttest for practical skills test scores increased for all respondents.

$$
\text { A very significant }
$$

improvement in leg practice skills by Indiaway. $100 \%$ of respondents have not done so and post test $100 \%$ of respondents do. (Roesli, 2016) said that the India way is to hold the baby's feet in the groin, as wields a bail soft and moved her hands down alternately, like milking. Prior to training, respondents just sort of leg up to the thigh without changing hands. After the training, participants can perform well in the first technique foot massage.

At the end of the movement on foot, many herbalists who missed it, namely by placing both baby's feet (Roesli, 2016), Increased very sharply also on the abdominal massage. In this technique, the respondents were taught as much as possible to massage the belly because if one of them is being massaged, the result is fatal. The average respondent in doing abdominal massage techniques are still not in accordance with the theory, which is massaged from top to bottom without understanding abdominal organ systems. After the demonstration of the methods of health education, $100 \%$ of respondents correctly understand and perform baby massage techniques abdomen ie pedaling technique, pedalling bicycle with their feet up, thumbs sideways, moon-sun technique, walking bubble technique, and ILU technique. Although respondents 
did not know the names of these techniques, but respondents do it coherently and well.

To massage the chest, before the demonstration methods of health education, respondents altready had to do it right. Massaging the next focus is on the head and face massage only. On average shamans still less skilled in doing massage of the head, because there are some respondents still hold the top of the head. Should be massaged on the face of it, because the baby's head has not fully developed. In the provision of health education is provided in detail massage on the forehead, eyebrows, nose, mouth, mouth down, a small circle in the jaw and behind the ear (Reosli, 2016). 99\% of respondents already do it properly and coherently.

When health education of baby massage demonstration method, respondents were very enthusiastic in participating in these activities. In addition to the awareness that perform baby massage that is inconsistent with the theory would be harmful to the baby, massage is a priority of the respondents work. In addition, respondents directly practiced on a little doll, so that respondents do the demonstration immediately and it can be viewed directly when researchers perform movements baby massage on dolls and respondents were directly told to re-demonstration, so that respondents can quickly grasp the material and recall baby massage movements. While doing the posttest, the researchers asked a shaman to perform the practice of baby massage from the feet first, followed massage the abdomen and chest, hands, face, and back.

Assessment is done per techniques with the assistance given sequence by researchers. The language when giving health education is not a barrier, because the shamans are very modern and understand Indonesian language. Demonstrations also show the procedure using the tool, so that the respondents be more understanding and informed about the practices they need to do, although not all techniques shaman can do it perfectly. Constraints in the provision of baby massage demonstration at the shaman is the difficulty of changing a culture that downly herrited been done by the respondent that need to be explained and exemplified baby massage techniques several times.

5. Analysis of Demonstration Method Effectiveness Against Shaman's Knowledge Level In Practicing Baby Massage.

Statistical analysis showed that contained significantly influence the provision of health education on baby massage demonstration methods of the level of knowledge of shamans, such as Daryanto theory (2009) is the method of demonstration effectively improve the level of knowledge. It is powered from an increase in significant results of the questionnaire given before and after the demonstration method.

The method is a way of presenting the material demonstration lesson by demonstrating or showing respondents a process being studied and the situation with verbal explanation. In accordance with the benefits of health promotion media 
that the media can clarify the presentation of messages and information so as to facilitate and enhance the learning process and results, as well as the media can enhance and direct the attention of the respondent which can cause learning motivation, the direct interaction between the learners and the environment. In this study, the provision of health education mtode demonstration using props puppets accompanied by verbal explanations, so that information can be directly delivered. Respondents also can respond or ask directly if researchers express less clear.

Provision of health education demonstration method demonstration showed that the method could be elected to facilitate the delivery of a message either verbally or practices, so that the respondent will be easy meningat and influencing knowledge. Also, how to bring the message by researchers to be a factor that strongly supports, according to (Notoatmodjo, 2011) behavior can be changed if the stimulus given really exceed the original stimulus. This stimulus should be able to convince the organism that can change a person's behavior. Creating a conducive environment to convince respondents that the researchers were able to and beneficiaries of the trust by respondents strongly affect the absorption of knowledge respondents. In addition, health workers should always update the knowledge of baby massage by reading books or journals to understand the detail about the benefit and may perform regular training to shamans and straighten the myths that exist in society

6. Analysis of Demonstration Method Effectiveness Against Shaman Practices in Baby Massage options. Demonstration method effectiveness against the practice of baby massage by herbalists based on the results of statistical analysis Paired T-Test. Researchers chose the demonstration method in order to get a clear picture of thingsrelated with the process of arranging things, the process of making things, the working process, comparing something else and to know and see the truth of something (Nursalam 2008) so it's important demonstration method for the provision of baby massagepractice.

Practice, according to (Notoatmodjo, 2012) ie knowing the stimulus or health object and then hold a vote or opinion on what is known, the next process is expected to carry out or practiced. Researchers provide demonstrations to influence the practice of the method as it has 3 levels that will become the benchmark one's habit, the guided response (quided response), mechanism (mechanism) and adoption (adoption). These stages are skills improvement experienced by respondents of baby massage demonstration method started from imitating the example, becomes a habit and will develop well in the correct order.

The baby massage demonstration using small doll in human form so that the respondent could pursue it as if that little doll props it is the baby so that respondents are more enthusiastic and facilitate respondents in 
receiving health information of baby massage demonstration. This method was followed by a verbal explanation or directly, so that in the opinion Ambarsari (2017) which has the result that there are significant extension consists of a lecture and demonstration by the practice of baby massage.

Demonstration method is a combination of oral and practice to get a clear picture of matters relating to the process of arranging things, the process of making things, the workings of something, the process of working on it or use it, comparing something with others and to know and see the truth of something (Nursalam 2008), Based on the analysis of the respondents have sufficient. knowledge of baby massage situation, respondents enthusiastically participated in the learning process of health education demonstration methods that can be caused respondents were active, how to explain a good researcher, there is a midwife who is responsible so that the respondents

\section{Conclusion and Suggestions. \\ Conclusion}

1. The level of knowledge of baby massage by shamans in Selopampang and Tembarak Public Health Center, before being given demonstration methods of health education is $38.7 \%$ or 12

2. Overview of the implementation of baby massage practice by shaman in Puskesmas and Selopampang and Tembarak Public Health Center, before being given health education demonstration method is $58.1 \%$ or as many as 18 people have good practical skills of baby massage.

3. The level of knowledge of baby massage by shamans in have more convince and awareness of the respondents that the training is important because if one of the skillsdid, will result can be fatal.

Health education requires appropriate media so that information can be received by the public health. This demonstration method could be one option for respondent in learning and solutions in health promotion to attract people so that people can play an active role in maintaining good health. The appropriate medium according to Sanjaya (2009) allows the delivery of information to become more effective and efficient due to the demonstration of verbal media can be avoided, the learning process more interesting and comparing between theory and reality. Health personnel such as midwives are expected to update the knowledge by reading books, seminars, and workshops on the development of medical science today that is no longer the cultural cornerstones of a health system.

Selopampang and Tembarak Public Health Center, Temanggung after being given a demonstration of the methods of health education were 19 respondents, or by $61.3 \%$ had good knowledge

4. Overview of the implementation of baby massage practice by shamans in Selopampang and Tembarak Public Health Center, Temanggung after being given a demonstration of the methods of health education is 17 or as much as $54.8 \%$ of respondents have good practical skills.

5. Giving a health education of demonstration and method is effective in improving knowledge of shamans. 
6. Giving health education of demonstration and method is effective in improving the practice of shamans.

\section{Suggestion}

1. For Medicals

Health workers are expected to update the science of baby massage by reading the latest baby massage techniques and understand its benefits in detail so as to provide training to the shaman and straighten the myths that exist in the community and to improve the skills of baby massage by herbalists.

2. For Health Agencies

Expected to always improve and develop trained that has done every month, as well as quack close embrace with public. Develop a shaman skills with theory and recent research that shaman skills not only based on the culture and beliefs.

3. For Shamans

Expected to apply baby massage skills according to the latest theory and research, so that the benefits of baby massage can be obtained maximally. In addition massage with the correct technique, babies will be healthy and help the growth well in order to become the high quality of the next generation.

\section{References}

Ambarsari. (2017). The Effect of Infant Massage Counseling on Infant Massage Practice by Mothers in Tugu Village , Jumantono SubDistrict, Karanganya, 1(2), 73-78. Ambarwati. (2011). Asuhan Kebidanan
Nifas. Yogyakarta: Mitra

Azwar. (2016). Sikap Manusia. Yogyakarta: Pustaka Pelajar.

Darah Ifalahma. (2016). INFOKES , VOL 6 NO 2 , November 2016 ISSN : 2086 - 2628, 6(2), 1-4.

Daryanto. 2009. Media Pembelajaran. Yogyakarta: Gava Media

Notoatmodjo. (2010). Promosi Kesehatan. Jakarta: PT Asdi Mahasatya.

Notoatmodjo. (2011). Pendidikan dan Perilaku Kesehatan. Jakarta: PT Rineka Cipta.

Notoatmodjo. (2012). Metodologi Penelitian Kesehatan. Jakarta: PT Rineka Cipta.

Nursalam. (2008). Konsep Penerapan etodologi Penelitian Ilmu Keperawatan. (Salemba Medika, Ed.). Jakarta: Salemba Medika.

Prawirohardjo. (2011). ilmu kebidanan. Jakarta: Tridasa Printer.

Roesli. (2016). Pedoman Pijat Bayi. Jakarta: PT. Trubus Agriwidy.

Sanjaya. (2009). Strategi Pembelajaran Berorientasi Standar Proses Pendidikan. Jakarta: Prenada.

Setyaningsih, R., Wati, K. E. P., \& Utami, A. (2015). Hubungan pijat bayi dengan perkembangan motorik bayi usia $1-12$ bulan di desa pundungsari bulu sukoharjo, $3(1), 9$.

Sudarsih. (2015). Pengaruh Pijat Bayi terhadap Kuantitas Tidur bayi usia 3-6 bulan di Desa Leminggir Kecamatan Mojosari Kabupaten Mojoketo, 07(03), 111-115.

Wawan dan dewi. (2011). teori \& pengukuran pengetahuan, sikap, dan perilaku manusia (II). Yogyakarta: Muha Medika. 